\title{
Evaluation of Different Varieties of Onion and Their Transplanting Times for Off-Season Production in Mid Hills of Nepal
}

\author{
Ishwori P. Gautam, Bhogendra Khatri and Govinda P. Paudel \\ Regional Agricultural Research Station-NARC, Lumle, Kaski, Nepal
}

\begin{abstract}
A field experiment was conducted at the agro-ecological research site (AER site) of the Regional Agriculture Regional Station, Lumle, at Deurali in Palpa (1200 masl) during rainy season of 2004 and 2005. The main objective of the experiment was to evaluate the different varieties of onion and their transplanting time for off-season production in mid hill conditions. Treatments were four onion varieties, namely LR-241, N-53, Nasik Red and Red Creole and four transplanting dates as 25 July, 5 August, 15 August, and 25 August. The trial was conducted in RCBD with factorial arrangement of treatments and replicated three times considering farmer as a replication. The plot size was maintained $1.4 \mathrm{~m}^{2}\left(1.4 \times 1 \mathrm{~m}^{2}\right)$. Observation was recorded on plant height, plant stand at maturity, diameter and length of bulbs, neck thickness and yield of green bulbs and green tops. The varieties showed a significant different only on the fresh bulb production. Transplanting dates showed a significant difference on the plant height, plant stand at maturity and marketable bulb production. The highest fresh bulb yield $\left(16.63 \mathrm{t} \mathrm{ha}^{-1}\right.$ observed on the variety N-53. Similarly, August 15 transplanting date produced the highest bulb yield $\left(15.31 \mathrm{tha}^{-1}\right)$ among four transplanting dates. This novel technology for off-season onion bulb production through seedlings would be good opportunity for increasing the income of many hill farmers which have no access to low land and irrigation facility during normal onion production season. The production of green tops in this period is consumable and easily saleable in the local market. So farmers get extra income from this technology.
\end{abstract}

Key words: Bulb yield, off-season onion, transplanting date, varieties

\section{INTRODUCTION}

The onion (Allium cepa L.) is an important vegetable crop in Nepal based on per capita consumption, area under cultivation and number of house-holds involved in farming (Budhathoki 1997). It stands at the third position in production among the vegetable crop in the world after tomato and cabbage (FAO 1996). The per capita consumption of fresh onion in Nepal is $7.7 \mathrm{~kg}$, which is very low than recommendation of $18 \mathrm{~kg}$ per annum. The in-country production of onion which accounts less than $50 \%$ of total supplies in the major market centers of Nepal even during the harvesting season ie from April to June (Koirala et al 1995) will not fulfilled the demand of our requirement. Nepal is importing large quantity of dry onion bulbs every year from India and overseas to full filled the demand of Nepalese farmers. Besides India, Nepal imported dry onion bulbs, which account $\$ 6788.40$ (NRs 4,88,768) from overseas in 2002/2003 (MoAC 2002/2003). Onion is physiologically a long-day plant and normally planted in Rabi season (October/November) and harvested in the months of May/June. However, there is a steady demand of onion bulb throughout the year. The storage of onion bulbs for long duration in ordinary conditions posses a great problem due to high humidity and high temperature from June to September. Storage report indicated that there was $43.9 \%$ storage loss of onion in different storage method without curing of bulbs and 31.9\% even after curing over the storage period of 4 months (Bhattarai and Subedi 1998). The loss caused in storage was due to sprouting, rotting, rooting and shrinkage. So, farmers are compelled to sale their product at minimum price at harvesting time, where as there is increase in the price and scarcity of dry onion bulbs from September onwards in the markets. 
To full fill the demand of onion during off-season the alternative methods for onion production through sets have been developed but farmers did not fully adopted this technology due to poor yield and difficult to produce and storage of standardizes sets. The rainy season onion production through use of sets have been tested at Rising Patan (400 masl), Sigana (1000 masl), Lumle (1600 masl) and Lopre (2200 masl). Among these tested sites the crop was failed to produce any yield at Lopre (2200 masl) and showed very poor yield in other sites $1.92,5.55,1.24 \mathrm{t} \mathrm{ha}^{-1}$ respectively, at Rising Patan, Sigana and Lumle (Bhattarai et al 1994).

In India, farmers are growing short duration variety (which requires less than 12 hours photo period) during rainy season through use of seedlings, which shares about $39.55 \%$ of total onion production in that country (Gautam 2001). However, the research on use of seedlings, appropriate variety and their planting time for off-season dry bulb production is lacking in Nepal. Therefore, this study was conducted to evaluate the different varieties of onion and their transplanting times for off-season onion production through use of seedlings in AER site Palpa during the rainy season of 2004 and 2005.

\section{MATERIALS AND METHODS}

The study was conducted at the AER site Deurali (1200 masl) in Palpa district during the rainy season of 2004 and 2005. The treatments consist of combinations of four onion varieties, namely LR-241, N-53, Nasik Red and Red Creole and four transplanting dates as 25 July, 5 August, 15 August and 25 August. The trial was conducted in RCBD with factorial arrangement of treatments and replicated three times considering farmer as a replication. The plot size was $1.4 \mathrm{~m}^{2}(1.4-\times 1-\mathrm{m})$.

Onion seeds were sown in raised nursery bed starting from $10^{\text {th }}$ June at 10 days intervals. The young seedlings were protected from heavy rainfall by providing plastic tunnel. One protective spray of Bavistin $\left(1.5 \mathrm{ml} \mathrm{l}^{-1}\right.$ water) was done against damping off in nursery beds. About $15-20 \mathrm{~cm}$ and 45 days old seedlings were transplanted at a spacing of 20- $\times 10-\mathrm{cm}$. Fertilizers was applied at the rate of $20 \mathrm{t} \mathrm{ha}^{-1}$ compost and 100:50:100 kg N: $\mathrm{P}_{2} \mathrm{O}_{5}: \mathrm{K}_{2} \mathrm{O}$ t ha ${ }^{-1}$. The half dose of nitrogen and full dose of phosphorus and potash was applied at the time of final land preparation and remaining half dose of nitrogen was top-dressed equally two times at 45 and 90 after transplanting of seedlings. Drainage canal was made around the plot to drain the excess water. Weeding and other intercultural operations were carried out as per the normal season onion. Neck fall was not observed in maturity stage during this season so the crop was harvested when flowering stalks started to appear. Immediately after harvesting the green tops were separated by leaving 2.5 $\mathrm{cm}$ neck. Observation was recorded on plant height, plant stand at maturity, diameter and length of bulbs, neck thickness and yield of green bulbs and green tops.

\section{RESULTS AND DISCUSSION}

\section{Plant height}

The plant height was measured at the maturity stage and average was computed. The pooled analysis of two year data showed there was a non significant difference on the height due to varieties. However, transplanting dates showed a highly significant difference on plant height. The longest plant height (59.81 $\mathrm{cm}$ ) was observed on the August 25 transplanting date and it was found at a par with August $5(56.81 \mathrm{~cm})$ transplanting date. Where as the shortest plant height $(39.7 \mathrm{~cm})$ was on July 25 transplanting date. The effect on the plant height due to interaction of varieties and transplanting dates was found non significant (Table 1).

\section{Neck diameter}

Neck diameter (thickness) in onion is an important character, because it indicates bulb storage ability. The onion with thin neck diameter store better than thick diameter. The neck thickness of sampled 
plants was measured with the help of Vernier Caliper in centimeter $(\mathrm{cm})$. The four tested varieties and interaction of varieties and transplanting dates showed a non significant difference on the neck diameter. However, transplanting dates showed a significant difference on neck diameter. The lowest average neck diameter $4.35 \mathrm{~cm}$ and $4.78 \mathrm{~cm}$ was found on July 25 transplanting dates, respectively in first and second year. The detail of different varieties and planting dates is presented in Table 2. The high neck thick ness in the all treatments was due to measurement of thickness of plant just after harvesting. Furthermore, there was no toppling and sunken of neck during this season as it happened in normal season onion.

Table 1. Effect of varieties and transplanting dates on plant height of rainy season onion at Deurali, Palpa during 2004 and 2005

\begin{tabular}{|c|c|c|c|c|c|c|c|c|c|}
\hline \multirow[t]{2}{*}{ Treatments } & \multicolumn{7}{|c|}{2004} & 2005 & \multirow[t]{2}{*}{ Mean } \\
\hline & 25 July & 5 Aug & 15 Aug & 25 Aug & 25 July & 5 Aug & 15 Aug & 25 Aug & \\
\hline LR-241 & 41.75 & 56.50 & 53.75 & 63.30 & 41.75 & 56.50 & 53.75 & 63.30 & 50.64 \\
\hline $\mathrm{N}-53$ & 43.10 & 55.15 & 54.15 & 59.45 & 43.10 & 55.15 & 54.15 & 59.45 & 51.95 \\
\hline Nasik Red & 37.70 & 57.85 & 47.15 & 54.85 & 37.70 & 57.85 & 47.15 & 54.85 & 47.77 \\
\hline Red Creole & 36.25 & 56.95 & 40.15 & 61.65 & 36.25 & 56.95 & 40.15 & 61.65 & 48.65 \\
\hline Mean & 39.70 & 56.81 & 48.88 & 59.81 & 39.70 & 56.81 & 48.88 & 59.81 & 49.75 \\
\hline F-test & $\begin{array}{c}\text { Variety } \\
\text { ns }\end{array}$ & \multicolumn{3}{|c|}{ Transplanting date } & \multicolumn{3}{|c|}{ Variety $\times$ Transplanting date } & & \\
\hline LSD (0.05) & - & & 5.039 & & & & & & \\
\hline
\end{tabular}

Table 2. Effect of varieties and transplanting dates on neck diameter of rainy season onion at Deurali, Palpa during 2004 and 2005

\begin{tabular}{|c|c|c|c|c|c|c|c|c|c|}
\hline \multirow[t]{2}{*}{ Treatments } & \multicolumn{7}{|c|}{2004} & 2005 & \multirow[t]{2}{*}{ Mean } \\
\hline & 25 July & 5 Aug & 15 Aug & 25 Aug & 25 July & 5 Aug & 15 Aug & $25 \mathrm{Aug}$ & \\
\hline LR-241 & 4.00 & 4.90 & 4.20 & 4.60 & 5.05 & 5.00 & 5.75 & 6.35 & 4.98 \\
\hline $\mathrm{N}-53$ & 4.55 & 4.10 & 4.25 & 5.60 & 5.65 & 5.55 & 5.90 & 6.55 & 5.27 \\
\hline Nasik Red & 4.47 & 5.30 & 4.15 & 5.15 & 3.95 & 6.35 & 5.35 & 6.10 & 5.10 \\
\hline Red Creole & 4.40 & 3.25 & 5.25 & 4.90 & 4.45 & 6.50 & 5.80 & 6.90 & 5.18 \\
\hline Mean & 4.32 & 4.39 & 4.46 & 5.06 & 4.48 & 5.85 & 5.70 & 6.48 & 5.13 \\
\hline F-test & $\begin{array}{c}\text { Variety } \\
\text { ns }\end{array}$ & \multicolumn{3}{|c|}{ Transplanting date } & \multicolumn{3}{|c|}{ Variety $\times$ Transplanting date } & & \\
\hline $\operatorname{LSD}(0.05)$ & - & & 0.830 & & & & & & \\
\hline
\end{tabular}

\section{Harvesting date}

The mean harvesting date was 156 days after transplanting. However, the harvesting date for the first year was longer than the second year. There was decreased in harvesting date for later transplanting (Table 3). The varieties and their interaction with transplanting dates showed a non significant difference on harvesting date. However, transplanting dates showed a highly significant difference on it.

Table 3. Effect of varieties and transplanting dates on harvesting date of rainy season onion at Deurali, Palpa during 2004 and 2005

\begin{tabular}{|c|c|c|c|c|c|c|c|c|c|}
\hline \multirow[t]{2}{*}{ Treatments } & \multicolumn{7}{|c|}{2004} & 2005 & \multirow[t]{2}{*}{ Mean } \\
\hline & 25 July & $5 \mathrm{Aug}$ & $15 \mathrm{Aug}$ & 25 Aug & 25 July & $5 \mathrm{Aug}$ & $15 \mathrm{Aug}$ & 25 Aug & \\
\hline LR-241 & 170 & 160 & 157 & 147 & 163 & 150.5 & 145.5 & 155.5 & 156.06 \\
\hline $\mathrm{N}-53$ & 170 & 160 & 157 & 147 & 163 & 150.5 & 145.5 & 155.5 & 156.06 \\
\hline Nasik Red & 170 & 160 & 157 & 147 & 163 & 150.5 & 145.5 & 155.5 & 156.06 \\
\hline Red Creole & 170 & 160 & 157 & 147 & 163 & 150.5 & 145.5 & 155.5 & 156.06 \\
\hline Mean & 170 & 160 & 157 & 147 & 163 & 150.5 & 145.5 & 155.5 & 156.06 \\
\hline & Variety & \multicolumn{3}{|c|}{ Transplanting date } & \multicolumn{3}{|c|}{ Variety $\times$ Transplanting date } & & \\
\hline F-test & ns & \multicolumn{3}{|c|}{$* * *$} & \multicolumn{3}{|c|}{ ns } & & \\
\hline LSD (0.05) & - & \multicolumn{3}{|c|}{5.128} & \multicolumn{3}{|c|}{-} & & \\
\hline
\end{tabular}




\section{Bolting percentage of plant}

The mean bolted of the plant was observed 2.22 percentage. Before implementation of the experiment it was assumed that the long day onion variety Red Creole would bolt and may not produce bulb, but the bolting percentage on Red Creole was found non significant difference among other varieties. The four transplanting dates and their interaction with varieties were also fond non-significant on the bolting percentage (Table 4). Results showed that bolting of onion plant is not affected by day length only and there may be other factors such as temperature, nutrients, status of the field etc, which could modify the bolting of the plant.

Table 4. Effect of varieties and transplanting dates on bolting percentage of rainy season onion at Deurali, Palpa during 2004 and 2005

\begin{tabular}{|c|c|c|c|c|c|c|c|c|c|}
\hline \multirow[t]{2}{*}{ Treatments } & \multicolumn{7}{|c|}{2004} & 2005 & \multirow[t]{2}{*}{ Mean } \\
\hline & 25 July & 5 Aug & 15 Aug & 25 Aug & 25 July & $5 \mathrm{Aug}$ & 15 Aug & 25 Aug & \\
\hline LR-241 & 3.51 & 3.51 & 3.51 & 3.51 & 3.1 & 1.27 & 0.00 & 0.00 & 2.30 \\
\hline $\mathrm{N}-53$ & 3.51 & 3.51 & 3.51 & 3.51 & 1.85 & 1.10 & 0.92 & 0.00 & 2.24 \\
\hline Nasik Red & 3.51 & 3.51 & 3.51 & 3.51 & 0.00 & 0.00 & 0.46 & 0.00 & 1.81 \\
\hline Red Creole & 3.51 & 3.51 & 3.51 & 3.51 & 5.00 & 0.00 & 1.25 & 0.00 & 2.54 \\
\hline Mean & 3.51 & 3.51 & 3.51 & 3.51 & 2.49 & 0.59 & 0.66 & 0.00 & 2.22 \\
\hline F-test & $\begin{array}{c}\text { Variety } \\
\text { ns }\end{array}$ & & $\begin{array}{c}\text { splanting } \\
\text { ns }\end{array}$ & & Variety $>$ & ranspla & date & & \\
\hline
\end{tabular}

\section{Diameter of Fresh bulb}

The diameter of the bulb was measured just after harvesting and average data are being presented in Table 5. There was significance difference on diameter of bulb due to varieties. However, transplanting date and their interaction with varieties showed a non-significant difference on bulb diameter. The highest mean diameter $(5.73 \mathrm{~cm})$ was found on N-53 and lowest $(4.90 \mathrm{~cm})$ was found on Red Creole.

Table 5. Effect of varieties and transplanting dates on bulb diameter of rainy season onion at Deurali, Palpa during 2004 and 2005

\begin{tabular}{|c|c|c|c|c|c|c|c|c|c|}
\hline \multirow[t]{2}{*}{ Treatments } & \multicolumn{7}{|c|}{2004} & 2005 & \multirow[t]{2}{*}{ Mean } \\
\hline & 25 July & 5 Aug & $15 \mathrm{Aug}$ & $25 \mathrm{Aug}$ & 25 July & 5 Aug & $15 \mathrm{Aug}$ & $25 \mathrm{Aug}$ & \\
\hline LR-241 & 5.35 & 5.00 & 5.61 & 5.06 & 5.70 & 6.10 & 5.91 & 5.35 & 5.51 \\
\hline $\mathrm{N}-53$ & 5.55 & 5.56 & 5.20 & 5.00 & 5.85 & 5.76 & 6.08 & 6.82 & 5.73 \\
\hline Nasik Red & 5.52 & 4.97 & 4.97 & 5.06 & 5.51 & 6.15 & 5.82 & 5.84 & 5.48 \\
\hline Red Creol & 5.02 & 4.74 & 4.76 & 5.18 & 4.48 & 5.83 & 4.27 & 4.93 & 4.90 \\
\hline \multirow[t]{2}{*}{ Mean } & 5.36 & 5.07 & 5.13 & 5.08 & 5.39 & 5.96 & 5.52 & 5.73 & 5.40 \\
\hline & Variety & \multicolumn{3}{|c|}{ Transplanting date } & \multicolumn{3}{|c|}{ Variety $\times$ Transplanting date } & & \\
\hline $\begin{array}{l}\text { F-test } \\
\text { L SD }(005)\end{array}$ & $\begin{array}{c}* \\
0494\end{array}$ & & ns & & & $\mathrm{s}$ & & & \\
\hline
\end{tabular}

\section{Length of Fresh bulb}

Higher length of bulb is a disqualification in case of onion. In this experiment none of the varieties, neither transplanting dates nor their interaction showed a significant difference on the length of fresh bulb. However the length of bulb varied from 3.89 to $7.71 \mathrm{~cm}$ with an average of $4.39 \mathrm{~cm}$. The detail data is presented in Table 6.

\section{Marketable Fresh bulb yield}

The yield of fresh onion bulb was significantly affected by both varieties and transplanting dates. The mean highest fresh bulb $\left(16.6 \mathrm{tha}^{-1}\right)$ was observed on the variety $\mathrm{N}-53$ where as lowest yield $\left(7.25 \mathrm{tha}^{-}\right.$ $\left.{ }^{1}\right)$ was recorded on Red Creole. 
Table 6. Effect of varieties and transplanting dates on bulb length of rainy season onion at Deurali, Palpa during 2004 and 2005

\begin{tabular}{|c|c|c|c|c|c|c|c|c|c|}
\hline \multirow[t]{2}{*}{ Treatments } & \multicolumn{7}{|c|}{2004} & 2005 & \multirow[t]{2}{*}{ Mean } \\
\hline & 25 July & 5 Aug & $15 \mathrm{Aug}$ & 25 Aug & 25 July & 5 Aug & 15 Aug & $25 \mathrm{Aug}$ & \\
\hline LR-241 & 3.95 & 4.0 & 4.90 & 3.20 & 4.55 & 5.25 & 4.25 & 4.70 & 4.35 \\
\hline $\mathrm{N}-53$ & 3.90 & 4.40 & 3.65 & 3.85 & 4.45 & 4.60 & 4.25 & 4.10 & 4.15 \\
\hline Nasik Red & 5.60 & 5.35 & 4.60 & 4.40 & 4.00 & 4.80 & 4.50 & 5.45 & 4.84 \\
\hline Red Cre & 3.65 & 4.0 & 4.30 & 4.10 & 4.20 & 4.80 & 4.20 & 4.60 & 4.23 \\
\hline Mean & 4.27 & 4.44 & 4.36 & 3.89 & 4.40 & 4.86 & 4.30 & 4.71 & 4.39 \\
\hline F-test & $\begin{array}{c}\text { Variety } \\
\text { ns }\end{array}$ & \multicolumn{3}{|c|}{ Transplanting date } & \multicolumn{3}{|c|}{ Variety $\times$ Transplanting date } & & \\
\hline
\end{tabular}

Similarly, different transplanting dates also showed a significant difference on the yield of onion. The highest bulb yield (15.31 tha ${ }^{-1}$ and $14.70 \mathrm{t} \mathrm{ha}^{-1}$ was observed on August 15 transplanting date respectively in first and second year. The lowest yield $\left(10.38 \mathrm{t} \mathrm{ha}^{-1}\right)$ was observed on August 5 transplanting date in first year and $9.19 \mathrm{t} \mathrm{ha}^{-1}$ on July 15 transplanting date in second year. The low yield in these transplanting dates could be due to unfavorable climatic condition like temperature and day length, field situation etc. The interaction effect of varieties and transplanting dates showed a non significant difference on the marketable yield of onion. The detail yield of varieties and their interaction with different transplanting dates is presented in Table 7 . Previously it was reported that the dry bulb production of onion during rainy season was not possible through seedling and it was done through sets. The bulb production through sets requires specific knowledge on production of specific size sets, required more time, and difficult to storage sets for longer period. Therefore the alternative method for onion bulb production through seedling was tested. The onion bulb production through seedling was practiced in India. The short days cultivars can initiate and form the bulbs under photoperiod of 12 hours or less. Besides photoperiod, environmental factors such as temperature, nutrition and spacing, and internal factors such as age of seedling and stage of development of plant control the development of bulbs.

Table 7. Effect of varieties and transplanting dates on fresh bulb yield of rainy season onion at Deurali, Palpa during 2004 and 2005

\begin{tabular}{|c|c|c|c|c|c|c|c|c|c|}
\hline \multirow[t]{2}{*}{ Treatments } & \multicolumn{7}{|c|}{2004} & 2005 & \multirow[t]{2}{*}{ Mean } \\
\hline & 25 July & 5 Aug & 15 Aug & $25 \mathrm{Aug}$ & 25 July & 5 Aug & 15 Aug & $25 \mathrm{Aug}$ & \\
\hline LR-241 & 13.25 & 7.50 & 13.75 & 13.13 & 11.29 & 10.29 & 17.36 & 11.96 & 12.32 \\
\hline $\mathrm{N}-53$ & 17.41 & 14.10 & 16.43 & 18.57 & 11.36 & 18.07 & 17.50 & 20.04 & 16.68 \\
\hline Nasik Red & 17.68 & 8.13 & 16.61 & 12.86 & 12.23 & 14.55 & 20.30 & 15.18 & 14.82 \\
\hline Red Creole & 9.82 & 11.79 & 14.46 & 11.43 & 0.88 & 3.39 & 3.62 & 2.64 & 7.25 \\
\hline Mean & 14.54 & 10.38 & 15.31 & 14.0 & 9.19 & 11.58 & 14.70 & 12.45 & 12.77 \\
\hline & Variety & \multicolumn{3}{|c|}{ Transplanting date } & \multicolumn{3}{|c|}{ Variety $\times$ Transplanting date } & & \\
\hline F-test & $* * *$ & & $*$ & & & & ns & & \\
\hline LSD $(0.05)$ & 2.712 & & 2.712 & & & & - & & \\
\hline
\end{tabular}

\section{Green top yield}

The green top yield of onion produced in off-season is also consumable and easily saleable in the local markets. So onion production in this season has great advantage to increase the income of poor farmers. The use of different varieties and different planting dates showed a significant difference on the production of green top yield (biomass). However, the interaction of varieties and transplanting dates showed a non significant difference on the green top yield. The average green top yield was recorded $6.14 \mathrm{t} \mathrm{ha}^{-1}$ and detail of the treatments is presented in Table 8. Based on the above results N-53 variety of onion is recommended for off-season (rainy season) production through seedling in mid hill condition. The best time of transplanting of seedling is recommended on August 15 in Palpa but it may vary in other places. Therefore further verification trials are needed in different agro-ecological condition. 
Table 8. Effect of varieties and transplanting dates on bulb diameter of rainy season onion at Deurali, Palpa during 2004 and 2005

\begin{tabular}{|c|c|c|c|c|c|c|c|c|c|}
\hline \multirow[t]{2}{*}{ Treatments } & \multicolumn{7}{|c|}{2004} & 2005 & \multirow[t]{2}{*}{ Mean } \\
\hline & 25 July & 5 Aug & 15 Aug & $25 \mathrm{Aug}$ & 25 July & 5 Aug & 15 Aug & $25 \mathrm{Aug}$ & \\
\hline LR-241 & 4.46 & 4.45 & 4.46 & 6.74 & 4.16 & 6.48 & 10.96 & 10.13 & 6.56 \\
\hline $\mathrm{N}-53$ & 5.30 & 5.25 & 5.36 & 7.55 & 3.96 & 7.61 & 11.25 & 14.07 & 7.54 \\
\hline Nasik Red & 6.30 & 4.89 & 3.90 & 5.47 & 4.73 & 7.75 & 7.05 & 11.25 & 6.42 \\
\hline Red Creole & 4.79 & 3.76 & 4.64 & 6.32 & 0.96 & 2.59 & 6.14 & 3.05 & 4.03 \\
\hline \multirow[t]{2}{*}{ Mean } & 5.21 & 4.59 & 4.68 & 6.52 & 3.53 & 6.11 & 8.85 & 9.63 & 6.14 \\
\hline & Variety & \multicolumn{3}{|c|}{ Transplanting dates } & \multicolumn{3}{|c|}{ Variety x Transplanting dates } & & \\
\hline F-test & * & & $*$ & & & & ns & & \\
\hline $\operatorname{LSD}(0.05)$ & 2.447 & & 2.447 & & & & & & \\
\hline
\end{tabular}

\section{ACKNOWLEDGMENT}

The authors would like to thank KP Upadhyay, JN Chaudhary for their technical help, Ram Jee Paudel and KP Devkota for assistance in the field work and RR Adhikari for computer work.

\section{REFERENCES}

Bhattarai SP and PP Subedi.1998. Effect of curing and storage method on post-harvest loss of bulb onion in low hills. LARC Working Paper No. 98/20. Lumle Agriculture Research Centre, Lumle, Kaski, Nepal. Pp. 3-5.

Bhattarai SP, B Adhikari and GB Gurung. 1994. Set size standardization and time of planting trial on off-season onion. LARC Working Paper No. 94/45. Lumle Agriculture Research Centre, Lumle, Kaski, Nepal. Pp 6-16.

Budhathoki K. 1997. The effects of environmental conditions on the growth and development of onions (Allium cepa, L.) in Nepal. Ph. D. Thesis. Department of Agriculture and Horticulture, Wye College, University of London.

FAO. 1996. Year book production. FAO Statistics Series Rome 55:29-150.

Gautam IP. 2001. Effect of nitrogen and boron on Kharif season onion production. M.Sc. Thesis. Chandra Sekhar Azad University of Agriculture and Technology, Kanpur, India.

Koirala GP, GB Thapa and GR Joshi.1995. Can Nepalese farmers compete in the domestic market? A comparison of the relative setting and performance in agriculture of Nepal and India. Research Report Series No. 34. Winrock International, PO Box 1313, Kathmandu, Nepal.

MoAC. 2002/2003. Statistical information on Nepalese agriculture 2002/03. Agribusiness Promotion and Statistics Division, Ministry of Agriculture and Cooperatives. HMG/N, Singhadarbar, Kathmandu, Nepal. 